\title{
Response of Rockwool-grown Greenhouse Cucumber, Tomato, and Pepper to Kinetin Foliar Sprays
}

\author{
A.P. Papadopoulos ${ }^{1,3}$, U. Saha ${ }^{1}$, X. $\mathrm{Hao}^{1}$, and S. Khosla ${ }^{2}$
}

AdDitional INDEX wORDs. cytokinin, dry weight, fresh weight, growth stimulant, KIN-Gro, leaf area, plant height, plant hormone, yield

\begin{abstract}
SuMMARY. Encouraging results from previous trials on field vegetables led to the expectation that a kinetin foliar spray from the commercial product KINGro (5000 ppm kinetin) on greenhouse vegetables would positively affect their growth and productivity. Thus, in this study, we evaluated the usefulness of this product on rockwool-grown 'Bodega' cucumber (Cucumis sativus), 'Rapsodie' tomato (Lycopersicum esculentum), and '4-Ever' and '444' pepper (Capsicum annuиm) at the Greenhouse and Processing Crops Research Centre of Agriculture and Agri-Food Canada, Harrow, Ont. Two replicated experiments were conducted to study the effect of kinetin spray on growth and production of all three crops: the first in Spring-Summer 2004 and the second in Fall-Winter 2004. Foliar sprays of kinetin at $\mathbf{2 . 5}, 5$, and $10 \mathrm{ppm}$ concentrations were tested against a water spray (control) on each crop. A 2.5-ppm kinetin spray had beneficial effects on the growth of cucumber transplants (taller plants and greater leaf area and fresh weight of leaves and stems). Furthermore, this treatment resulted in higher marketable yield in the Spring-Summer crop and in larger fruit size in the FallWinter crop. Regression analysis showed that cucumber marketable yield had an overall quadratic response to kinetin spray concentration in Spring-Summer season maximizing at $5.1 \mathrm{ppm}$ kinetin. Kinetin spray also had beneficial effects on the growth of tomato seedlings, but not on yield. On the other hand, significant beneficial effects were observed on the growth of pepper seedlings and on marketable yield and fruit quality. Regression analysis showed that the response of pepper marketable yield to kinetin spray concentration was positive and linear. It must be noted that, given the rather short-term nature of our experiments, the observed beneficial effects of the kinetin sprays on yield can only be interpreted as beneficial effects on early yield rather than on the total yield. We concluded that under our growing conditions, cucumber production would benefit from a dilute $(2.5 \mathrm{ppm})$ kinetin spray, and pepper production from a high concentration spray $(10 \mathrm{ppm})$; tomato transplant growth will also benefit from a kinetin spray at $2.5 \mathrm{ppm}$. The results of this study could be of considerable significance to the greenhouse vegetable industry.
\end{abstract}

$\mathrm{C}$ ytokinin is the generic name used to designate a group of plant hormones that regulate cell division and organogenesis in plant tissues (Barciszewski et al., 2000). A whole new class of synthetic cytokininlike compounds were developed after the discovery that diphenylurea (DPU) has cytokinin-like activity. $N(2$-chloro4-pyridyl)- $N^{\prime}$-phenylurea (CCPU) and thidiazuron (TDZ) are widely used synthetic cytokinins of this class (Flaishman et al., 2005).

Cytokinins have been shown to have effects on many physiological and

${ }^{1}$ Greenhouse and Processing Crops Research Centre, Agriculture and Agri-Food Canada, Harrow, Ont., Canada N0R IG0.

${ }^{2}$ Ontario Ministry of Agriculture and Food, Harrow, Ont., Canada, NOR IG0.

${ }^{3}$ Corresponding author: tel. 519.738.2251, ext. 423; fax: 519.738.2929; e-mail: papadopoulost@agr.gc.ca developmental processes (Barciszewski et al., 1998), including seed germination (Wilczek and $\mathrm{Ng}, 1982$ ), leaf expansion and development (Ulvskov et al., 1992), flower and fruit development (Ozga and Reinecke, 2003), nutrient mobilization and utilization (Gaudinova, 1990), apical dominance, chloroplast differentiation, and leaf senescence (Karagiannis and Pappelis,
1994). Apart from the studies on crop response to various plant hormones (both endogenous and exogenously applied), substantial research effort has been devoted to the use of naturally derived or synthetic biostimulants in agriculture (Russo and Berlyn, 1990). Biostimulants are non-nutritional products that may reduce fertilizer use, and increase yield and resistance to water and temperature stress (Russo and Berlyn, 1992). Commercial biostimulants that stimulate plant growth and yield (Russo and Berlyn, 1992) often contain humic acid, marine plant/algal extracts (carrying cytokinins), polymers of lactic acid, amino acids, B vitamins, and/or ascorbic acids in combination with different plant hormones. In some cases, they have shown a considerable potential for use in horticulture (Russo and Berlyn, 1990), but there is also considerable evidence that not all these substances work.

The practical application of plant growth regulators (PGR) and biostimulants in agricultural production is limited to only certain species, such as cucumber, tomato, pepper, potato (Solanum tuberosum), onion (Allium cepa), pea (Pisum sativum), and melon (Cucumis melo), with variable results. Staub et al. (1987) observed no positive effect of treating cucumber seeds with the commercial cytokinin-containing compounds Cytozyme ( $10 \%$ cytokinin v/v; Cytozyme, Salt Lake City, Utah) and Cytex (10\% cytokinin v/v; Atlantic and Pacific Research, Palm Beach, Fla.), on the rate and total emergence of seedlings, sex expression, maturity date, or fruit yield at three field locations. Root zone application of 5 to $230 \mathrm{~nm}(0.005-0.230 \mathrm{ppm})$ kinetin with nutrient solution in a recirculating solution culture system was not useful in promoting growth of tomato at either optimum $\left(25^{\circ} \mathrm{C}\right)$ or low $(15$ ${ }^{\circ} \mathrm{C}$ ) temperature (Bugbee and White, 1984). On the other hand, foliar or root applications of kinetin enhanced

\begin{tabular}{llll}
\hline $\begin{array}{l}\text { Units } \\
\text { To convert U.S. to SI, } \\
\text { multiply by }\end{array}$ & U.S. unit & SI unit & $\begin{array}{l}\text { To convert SI to U.S., } \\
\text { multiply by }\end{array}$ \\
\hline 29.5735 & $\mathrm{fl} \mathrm{oz}$ & $\mathrm{mL}$ & 0.0338 \\
0.0929 & $\mathrm{ft}^{2}$ & $\mathrm{~m}^{2}$ & 10.7639 \\
2.54 & inch $(\mathrm{es})$ & $\mathrm{cm}$ & 0.3937 \\
25.4 & inch $(\mathrm{es})$ & $\mathrm{mm}$ & 0.0394 \\
6.4516 & inch & $\mathrm{cm}^{2}$ & 0.1550 \\
1 & $\mathrm{mmho} / \mathrm{cm}$ & $\mathrm{mS} \cdot \mathrm{cm}^{-1}$ & 1 \\
28.3495 & $\mathrm{oz}$ & $\mathrm{g}$ & 0.0353 \\
1 & $\mathrm{ppm}$ & $\mathrm{mg} \cdot \mathrm{L}^{-1}$ & 1 \\
$\left({ }^{\circ} \mathrm{F}-32\right) \div 1.8$ & ${ }^{\circ} \mathrm{F}$ & ${ }^{\circ} \mathrm{C}$ & $\left(1.8 \times{ }^{\circ} \mathrm{C}\right)+32$
\end{tabular}


photosynthetic rates (Clifford et al., 1986), alleviated the harmful effects of oxygen and salt stress on growth (Younis et al., 2003), alleviated the light stress on photosynthesis (Dong and Arteca, 1982), modified favorably the internal production of plant growth regulators (Younis et al., 2003), or increased the yield of melon, potato, and pepper (Nickell, 1986). Studies conducted with foliar sprays of commercial seaweed extract biostimulants carrying phytohormones (auxins, cytokinins, and gibberellins), amino acids, carbohydrates, and some micronutrients resulted in increased leaf size in spinach (Spinacia oleracea), improved root growth of tomato (Verklej, 1992), and produced higher earlier yields with larger fruit size or higher total marketable yield in tomato throughout the season (Csizinszky, 1994). In studies conducted by Csizinszky (1986), cytokinin foliar sprays ( 14 and $28 \mathrm{~d}$ after transplanting) from Cytex on 'Sunny' tomato resulted in a great increase ( $70 \%$ over control) in the yield of large fruit, while the cultivar Hayslip appeared less responsive. Csizinszky et al. (1990) observed increased total marketable yield of pepper throughout the season in response to a combined soil and foliar application of a commercial biostimulant containing cytokinin as kinetin (Triggr; Westbridge Agricultural Products, San Diego), but the early yields or fruit size remained unaffected. Furthermore, these treatments did not increase the early or the total marketable yield of tomato (Csizinszky et al., 1990).

In summary, the literature suggests that the positive effects of commercial PGRs and biostimulants on fruit size, early yield, or total yield of field vegetables throughout the season were inconsistent from year to year, cultivar response was varied, but foliar application was the most efficacious route (Csizinszky, 1996; Vavrina, 2001). Thus, the necessity and benefits of using these products on vegetables have not been unequivocally established, warranting continuous research effort for the development of new products and their evaluation on various crops. Furthermore, there is a paucity of similar research results on the performance of commercial PGRs and biostimulants on greenhouse crops, which merits special attention.

Several cytokinin preparations are available today for application to agricultural crops. Claims made by the manufacturers include better root growth, enhanced leaf area and photosynthesis, improved stress tolerance, earlier shift of the plants from vegetative to reproductive state bringing about earliness in flowering and fruiting, increased fruit size, better nutrient translocation, ability to reduce pesticide applications, and improved efficiency of applied nutrients (Kelling, 2004).

KIN-Gro is a cytokinin preparation (with $5000 \mathrm{ppm}$ kinetin) produced by Agrowchem, Kingston, Ont., Canada. On the basis of positive results from previous trials on field vegetables, we hypothesized that a kinetin spray using KIN-Gro on greenhouse vegetables would positively affect their growth and productivity. In the present study, we conducted experiments to determine and quantify the biological activities of kinetin foliar applications from KIN-Gro on greenhouse-grown cucumber, tomato, and pepper growth, flower formation, and fruit production, thereby determining whether this product would be useful to the greenhouse vegetable industry.

\section{Materials and methods}

GeNERAL CROP HUSBANDRY. Research was conducted in the greenhouse facilities of Greenhouse and Processing Crops Research Centre of Agriculture and Agri-Food Canada, Harrow (lat. $42^{\circ} 16^{\prime} \mathrm{N}$, long. $82^{\circ} 58^{\prime} \mathrm{W}$ ), Ont. Two replicated experiments were conducted: the first in Spring-Summer 2004 and the second in Fall-Winter 2004.

The greenhouse vegetables studied were: English-type cucumber ('Bodega'), beefsteak-type tomato ('Rapsodie'), and bell-type pepper ('4Ever' and '444'). In both Spring-Summer and Fall-Winter experiments, seeds of tomato (Rogers, Syngenta Seeds, Boise, Idaho) and pepper (Enza Zaden Beheer B.V., Enkhuizen, The Netherlands) were sown in $4.0 \times 2.5$ $\times 2.5 \mathrm{~cm}$ rockwool cubes. All the rockwool growing media used in this study were FIBRgro Horticultural Products (Fibrex Insulations, Sarnia, Ont., Canada). Seeds of cucumber (Rijk Zwaan Nederland B.V., De Lier, The Netherlands) were also sown in $4.0 \times 2.5 \times 2.5 \mathrm{~cm}$ rockwool cubes in Spring-Summer, but they were direct-seeded into $10 \times 10 \times 10 \mathrm{~cm}$ rockwool blocks in Fall-Winter. Following germination, after the cotyle- dons became fully unfolded, seedlings were transplanted into $7.5 \times 7.5 \times 7.5$ $\mathrm{cm}$ rockwool blocks, in Spring-Summer. In Fall-Winter, the seedlings of tomato and pepper (cucumber was direct-seeded) were transplanted into $10 \times 10 \times 10 \mathrm{~cm}$ rockwool blocks. There was one plant per seedling block. Two hundred and fifty transplants were raised during each experiment for each of cucumber, tomato, and pepper. For both experiments, Tables 1 and 2 show the main cultural events.

Transplants were raised on benches at a density of 12 plants $/ \mathrm{m}^{2}$ until their final planting in the greenhouse. During the transplant rearing phase, the heating temperature was set at $18{ }^{\circ} \mathrm{C}$ while the ventilation/cooling set point was at $20^{\circ} \mathrm{C}$. Day/night air humidity was set at $60 \% / 55 \%$. Carbon dioxide concentration was maintained at $1000 \mathrm{ppm}$ with liquid carbon dioxide when the light intensity was $>75 \mathrm{~W} \cdot \mathrm{m}^{-2}$ and the greenhouse was not ventilated. Supplemental lighting was provided for the period $\mathrm{l} h$ before dawn to $\mathrm{l} h$ after dusk (13- to 18-h photoperiod) when the ambient light was $<500$ $\mathrm{W} \cdot \mathrm{m}^{-2}$ with high-pressure sodium lamps $\left(190 \mathrm{~W} \cdot \mathrm{m}^{-2}\right.$ as installed capacity; $\left.50 \mu \mathrm{mol} \cdot \mathrm{m}^{-2} \cdot \mathrm{s}^{-1}\right)$. A computer was used to control heating, ventilation, carbon dioxide enrichment, humidity, and light and to log environmental conditions. The transplants were fertigated using a Harrow Fertigation Manager (Climate Control Systems, Leamington, Ont., Canada) according to standard nutrient recommendations (Papadopoulos, 1991; Papadopoulos and Liburdi, 1989).

Final planting in the greenhouse was on rockwool slabs $(50 \times 20 \times 10$ $\mathrm{cm}$ for the Spring-Summer experiment and $100 \times 15 \times 7.5 \mathrm{~cm}$ for the Fall-Winter experiment); plant density in both cases was 2.5 plants $/ \mathrm{m}^{2}$. Plants were fertigated using a Harrow Fertigation Manager according to recommended fertigation schedules (Papadopoulos, 1991; Papadopoulos and Liburdi, 1989) with drippers delivering nutrient solution at the rate of $2 \mathrm{~L} \cdot \mathrm{h}^{-1}$. The fertigation frequency (four to six times per day), and duration of each fertigation event ( 4 to $10 \mathrm{~min}$ ), were increased progressively as the crops grew to supply 500, 750, 1000, and $2000 \mathrm{~mL}$ nutrient solution per plant per day for cucumber and tomato, and $500,750,1000$, and $1500 \mathrm{~mL}$ nutrient solution per plant per day for pepper as 
Table 1. Treatment description and chronology of cultural events during the Spring-Summer 2004 experiment on the response of rockwool-grown greenhouse cucumber, tomato, and pepper to kinetin foliar sprays.

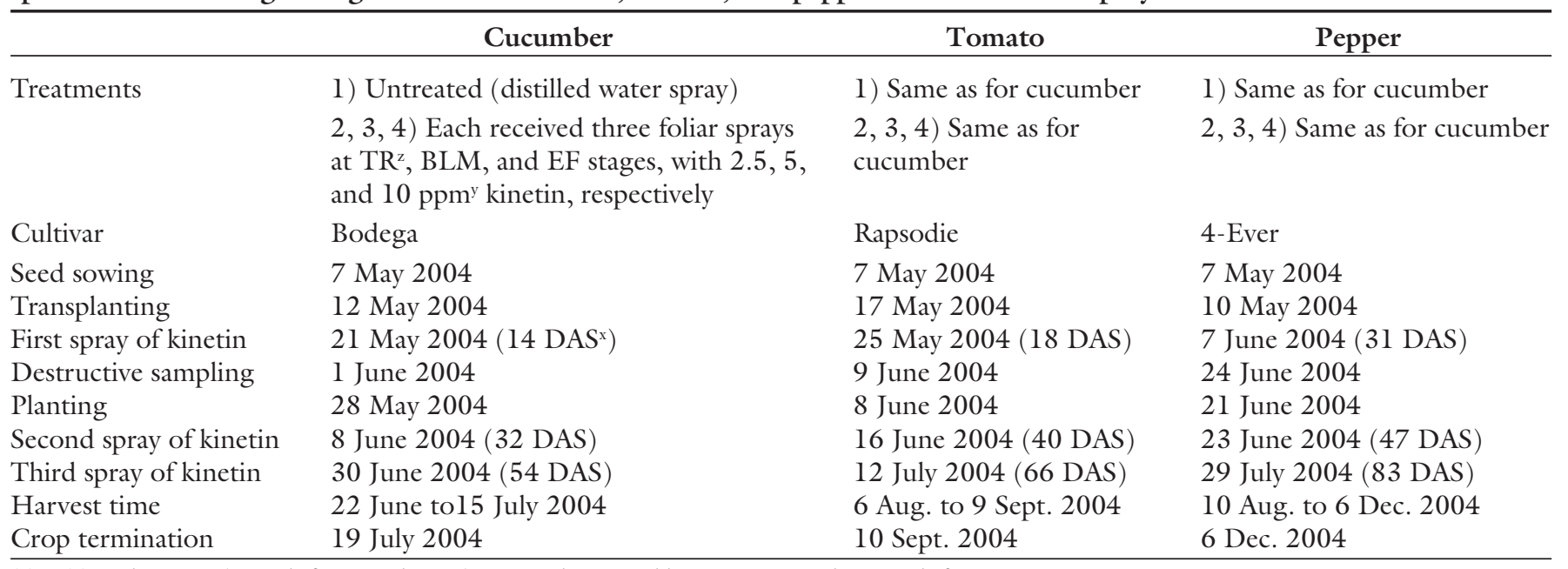

${ }^{2} \mathrm{TR}=$ Transplant stage $(7-10 \mathrm{~d}$ after transplanting $) ; \mathrm{BLM}=5 \%$ to $10 \%$ blooming stage; and $\mathrm{EF}=$ early fruiting stage.

${ }^{\mathrm{y}} \mathrm{l} \mathrm{ppm}=1 \mathrm{mg} \cdot \mathrm{L}^{-1}$.

${ }^{\times}$DAS $=$days after seed sowing

Table 2. Treatment description and chronology of cultural events during the Fall-Winter 2004 experiment on the response of rockwool-grown greenhouse cucumber, tomato, and pepper to kinetin foliar sprays.

\begin{tabular}{|c|c|c|c|}
\hline & Cucumber & Tomato & Pepper \\
\hline \multirow[t]{2}{*}{ Treatments } & 1) Untreated (distilled water spray) & 1) Same as for cucumber & 1) Same as for cucumber \\
\hline & $\begin{array}{l}2,3,4) \text { Each received three foliar sprays } \\
\text { at } \mathrm{TR}^{\mathrm{z}}, \mathrm{BLM} \text {, and } \mathrm{EF} \text { stages, with } 2.5,5 \text {, } \\
\text { and } 10 \mathrm{ppm}^{\mathrm{y}} \text { kinetin, respectively }\end{array}$ & $\begin{array}{l}2,3,4) \text { Same as for } \\
\text { cucumber }\end{array}$ & $2,3,4)$ Same as for cucumber \\
\hline Cultivar & Bodega & Rapsodie & 444 \\
\hline Seed sowing & 18 Aug. 2004 & 18 Aug. 2004 & 18 Aug. 2004 \\
\hline First spray of kinetin & 7 Sept. $2004\left(20\right.$ DAS $\left.^{x}\right)$ & 8 Sept. 2004 (21 DAS) & 22 Sept. 2004 (35 DAS) \\
\hline Destructive sampling & 14 Sept. 2004 & 29 Sept. 2004 & 13 Oct. 2004 \\
\hline Planting & 9 Sept. 2004 & 17 Sept. 2004 & 7 Oct. 2004 \\
\hline Second spray of kinetin & 20 Sept. 2004 (33 DAS) & 4 Oct. 2004 (47 DAS) & 19 Oct. 2004 (62 DAS) \\
\hline Third spray of kinetin & 28 Sept. 2004 (41 DAS) & 18 Oct. 2004 (61 DAS) & 16 Nov. 2004 (90 DAS) \\
\hline Harvest time & 1 Oct. 28 Oct. 2004 & 25 Nov. 2004 to 7 Feb. 2 & 5 Jan. to 7 Feb. 2005 \\
\hline
\end{tabular}

${ }^{2} \mathrm{TR}=$ Transplant stage $(7-10 \mathrm{~d}$ after transplanting $) ; \mathrm{BLM}=5 \%$ to $10 \%$ blooming stage; and EF = early fruiting stage.

${ }^{\mathrm{y}} \mathrm{l} \mathrm{ppm}=1 \mathrm{mg} \cdot \mathrm{L}^{-1}$.

${ }^{x} \mathrm{DAS}=$ days after seed sowing

the overall targets in different phases. The $\mathrm{pH}$ and electrical conductivity (EC) of feeding nutrient solutions, and of the leaching or extracted solutions from the growth media were measured regularly (three to five times weekly). Fine adjustment of nutrient feeding (feed formula, fertigation frequency, and duration) was based on the measured values of EC and $\mathrm{pH}$ (of both feeding nutrient and extracted solution), leach fraction, and according to plant age and climatic conditions (Papadopoulos, 1998). The adopted fertigation schedules maintained a desired leach fraction in the ranges of $20 \%$ to $40 \%$ and $20 \%$ to $35 \%$ during Spring-Summer and Fall-Winter experiments, respectively. Over the grow- ing seasons, the leachates had a $\mathrm{pH}$ of 5.5 to 7.3 during the Spring-Summer experiment and $\mathrm{pH} 5.4$ to 6.9 during the Fall-Winter experiment. The leachate EC varied from 2.2 to $4.5 \mathrm{mS} \cdot \mathrm{cm}^{-1}$ during the Spring-Summer experiment and from 2.7 to $3.9 \mathrm{mS} \cdot \mathrm{cm}^{-1}$ during the Fall-Winter experiment. The day/night heating temperature was set at $19 / 18{ }^{\circ} \mathrm{C}$, while the ventilation/cooling set point was from 23 to $26^{\circ} \mathrm{C}$ and varied according to season and the growth stage of the plants. In the Spring-Summer experiment, the temperature inside the greenhouse during transplanting [TR ( 7 to $10 \mathrm{~d}$ after transplanting to the rockwool blocks)], $5 \%$ to $10 \%$ blooming [BLM (when $5 \%$ to $10 \%$ plants in the population showed blooming at their fruit production nodes)], and early fruiting [EF (7 to $10 \mathrm{~d}$ after first fruit set) ] stages ranged from 19.2 to $29.2^{\circ} \mathrm{C}, 19.3$ to 28.7 ${ }^{\circ} \mathrm{C}$, and 16.0 to $28.3^{\circ} \mathrm{C}$, respectively; corresponding temperature ranges for the Fall-Winter experiment were from 18.0 to $29.5^{\circ} \mathrm{C}, 18.9$ to 24.0 ${ }^{\circ} \mathrm{C}$, and 19.0 to $22.1^{\circ} \mathrm{C}$, respectively. Day/night relative humidity $(\mathrm{RH})$ was set at $70 \% / 65 \%$ in both experiments; in the Spring-Summer experiment, during TR, BLM, and EF stages, it ranged from $42.8 \%$ to $94.8 \%, 48.9 \%$ to $98.5 \%$, and $54.8 \%$ to $98.5 \%$, respectively; the corresponding $\mathrm{RH}$ ranges in the Fall-Winter experiment were $42.5 \%$ to $91.8 \%, 44.3 \%$ to $92.1 \%$, and $45.1 \%$ to $81.5 \%$, respectively. Carbon dioxide 
concentration in the greenhouse was maintained at $1000 \mathrm{ppm}$ with liquid carbon dioxide when the light intensity was $>75 \mathrm{~W} \cdot \mathrm{m}^{-2}$ and the greenhouse was not ventilated. A computer was used to control heating, ventilation, carbon dioxide enrichment, and $\mathrm{RH}$ and logged environmental conditions. Cucumber and tomato plants were trained to a single stem. Pepper plants were trained to a single stem but with two main branches (a "Y" canopy shape). Older and dead leaves were pruned once per week, as needed. In the cases of cucumber and pepper, the first three lower node flowers were removed. Above the fourth node, only a single fruit per node was allowed. On tomato, fruit was pruned regularly to four or five fruit per cluster.

EXPERIMENTAL DESIGN. In each of the two experiments, a water control and three different kinetin foliar spray treatments $(2.5,5.0$, and 10.0 ppm kinetin) were tested. The spray solutions of desired concentrations were made from the commercial product KINGro, a 5000-ppm kinetin preparation. On all three species, during each experiment, a foliar application was made at three different developmental stages: TR, BLM, and EF (Tables 1 and 2). For the first spray at the TR stage, 50 transplants for each of the four treatments were randomly selected (out of a population of 250), tagged, placed on four widely separated benches, and then sprayed with the test solutions. After the spray solutions had dried, the treated plants were returned back to the original bench and rearranged randomly to the original density of 12 plants $/ \mathrm{m}^{2}$. Plants were always sprayed to runoff, and hence the volume of spray applied varied with the crop and the stage of growth. The average volumes of spray solution used per plant at the TR stage were 50,30, and 90 $\mathrm{mL}$ for tomato, pepper, and cucumber, respectively. At the BLM stage, tomato, pepper, and cucumber required 400 , 200 , and $600 \mathrm{~mL}$ spray solution per plant, respectively. The spray volumes at the EF stage were $800 \mathrm{~mL} /$ plant for both tomato and cucumber, and 400 $\mathrm{mL} /$ plant for pepper. All the sprays were done using hand sprayers (Home Gardener U4900-1; Home Hardware Stores Ltd., Harrow, Ont., Canada).

A completely randomized experimental design was adopted for all of the seedling growth evaluations using single plant replication. At first, 20 test plants (out of 50) from each of the four treatments were randomly selected and tagged. Plant height, number of leaves, and stem diameter [determined at 10 $\mathrm{cm}$ below the tip using digital caliper (model no. 241-600-11; Marathon Watch Co., Richmond Hill, Ont., Canada) ] were determined on all of the 20 test plants. Leaf area was determined with a LI-3100C area meter (LI-COR Biosciences, Lincoln, Nebr.) using five plants chosen randomly from the 20 test plants in each treatment. Determinations of fresh and dry weights of leaves and stems were on the same five plants that were used for leaf area measurement. Leaf and stem samples were dried in an oven at $50{ }^{\circ} \mathrm{C}$ until constant dry weights of the samples were obtained (usually within $96 \mathrm{~h}$ ). After the destructive use of aforesaid five plants, the remaining 45 plants in each of the four treatments were respaced randomly on the bench to the original density of 12 plants $/ \mathrm{m}^{2}$.

During the crop production cycle, the experimental unit (plot) comprised four plants. The plots were laid out in a randomized complete-block design in both Spring-Summer (three replicates) and Fall-Winter (four replicates) experiments. Plant height, number of leaves, and stem diameter along with number of flowers and fruit on each plant (by cluster on tomato) were determined at planting time and then measured once per week in the Spring-Summer experiment and every other week in the Fall-Winter up to 6 weeks after planting. These measurements included all test plants in each crop (i.e., 12 plants per treatment in the Spring-Summer or 16 plants per treatment in the Fall-Winter). Fruit from each plot (four plants/plot) was harvested twice per week and graded into various marketable and unmarketable grades according to Ontario commercial standards (Ontario Ministry of Agriculture and Food, 1987). Fruit number and weight in each grade were recorded. Marketable tomato had three different size grades: extra-large, large, and small with fruit diameters of $>75 \mathrm{~mm}, 55$ to $75 \mathrm{~mm}$, and 40 to 55 $\mathrm{mm}$, respectively. Besides, there were commercial (based on shape) and no. 2 grades in marketable tomato. Marketable cucumbers were separated into four different size grades: extra-large, large, medium, and small, having the lengths of $>42 \mathrm{~cm}, 37$ to $42 \mathrm{~cm}, 32$ to $37 \mathrm{~cm}$, and 28 to $32 \mathrm{~cm}$, respectively.
The extra-large, large, medium, and small grades of marketable pepper were $>85 \mathrm{~mm}, 75$ to $85 \mathrm{~mm}, 65$ to $75 \mathrm{~mm}$, and 55 to $65 \mathrm{~mm}$ in diameter, respectively. Further details about the fruit grading systems adopted in this study can be obtained from Ontario Ministry of Agriculture and Food (1987).

Statistical anAlyses. All statistical analyses were performed using SAS (release 8.02 for Windows; SAS Institute Inc., Cary, N.C.). Data on each parameter were analysed based on the generalized linear model. The treatment means were separated with the least significant difference test (LSD, $P=0.05$ ), if the main treatment effect was significant at the $5 \%$ level in the analysis of variance. Correlations between kinetin spray concentrations and all transplant growth parameters were also performed, but only the significant ones are reported. Significant kinetin spray effects on marketable yield were further analysed for various polynomial effects (orthogonal contrasts) followed by appropriate regression analysis.

\section{Results}

Cucumber. Cucumber seedlings sprayed with $10 \mathrm{ppm}$ kinetin realized significant gains (over the water control) in plant height, leaf area, leaf fresh weight, and fresh and dry weight of stem (Table 3); these effects were observed in both experiments except for the leaf dry weight which was observed in the Fall-Winter crop only. Sprays with 2.5 and $5 \mathrm{ppm}$ solution of kinetin were, in most cases, as effective as 10 ppm kinetin. Except for stem dry weight in the Spring-Summer crop, leaf number in the Fall-Winter crop, and stem diameter in both crops, all the growth parameters of cucumber seedlings had significant positive correlations with the kinetin spray concentration at the $5 \%(*)$ or $1 \%(* *)$ level $(\mathrm{r}=0.29 * *$ and $0.43^{* *}$ for plant height; $0.52 * *$ for leaf number in Spring-Summer; $0.67^{* *}$ and $0.75^{* *}$ for leaf area; $0.69^{* *}$ and $0.66^{* *}$ for fresh weight of leaves; $0.48^{*}$ and $0.64^{* *}$ for fresh weight of stem; $0.53^{*}$ and $0.59^{* *}$ for dry weight of leaves; and $0.53^{*}$ for dry weight of stem in Fall-Winter). Furthermore, the correlation between the number of leaves and kinetin spray concentration in the Fall-Winter crop was significantly negative $\left(r=-0.28^{*}\right)$.

There was no significant effect of kinetin sprays on the growth of cucumber plants during the first six 
Table 3. Effects of kinetin sprays on the growth of 'Bodega' cucumber seedlings during the Spring-Summer and Fall-Winter 2004 seasons.

\begin{tabular}{|c|c|c|c|c|c|c|c|c|}
\hline \multirow{2}{*}{$\begin{array}{l}\text { Kinetin spray concn } \\
{\left[(\mathrm{ppm}) \mathrm{mg} \cdot \mathrm{L}^{-1}\right]}\end{array}$} & \multirow{2}{*}{$\begin{array}{l}\text { Plant ht }{ }^{\mathrm{z}} \\
(\mathrm{cm})^{\mathrm{x}}\end{array}$} & \multirow{2}{*}{$\begin{array}{c}\text { Leaves }^{\mathrm{z}} \\
\text { (no./plant) }\end{array}$} & \multirow{2}{*}{$\begin{array}{l}\text { Stem diam }^{\mathrm{z}} \\
(\mathrm{mm})^{\mathrm{x}}\end{array}$} & \multirow{2}{*}{$\begin{array}{c}\text { Leaf area } \\
\left(\mathrm{cm}^{2} / \text { plant }\right)\end{array}$} & \multicolumn{2}{|c|}{ 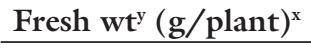 } & \multicolumn{2}{|c|}{ Dry wt $t^{\mathrm{y}}(\mathrm{g} /$ plant $)$} \\
\hline & & & & & Leaves & Stem & Leaves & Stem \\
\hline \multicolumn{9}{|c|}{ Spring-Summer 2004 ${ }^{\mathrm{w}}$} \\
\hline 2.5 & 64.0 & 10 & 9.6 & 2144 & 68.9 & 36.1 & 6.8 & 2.1 \\
\hline 5 & 59.0 & 11 & 9.6 & 2089 & 65.3 & 33.3 & 7.1 & 1.9 \\
\hline 10 & 59.2 & 11 & 9.3 & 2300 & 77.7 & 34.7 & 7.4 & 2.0 \\
\hline Fisher's protected $\operatorname{LSD}_{(0.05)}{ }^{\mathrm{u}}$ & 5.0 & --- & --- & 267 & 10.2 & 4.3 & --- & 0.3 \\
\hline \multicolumn{9}{|c|}{ Fall-Winter $2004^{\mathrm{t}}$} \\
\hline 0 (water) & 93.9 & 10.0 & 8.0 & 5118 & 131.3 & 69.0 & 11.9 & 3.4 \\
\hline 2.5 & 103.6 & 10.0 & 7.8 & 6334 & 145.0 & 76.9 & 12.6 & 3.8 \\
\hline 5 & 101.0 & 9.8 & 7.6 & 6464 & 135.2 & 73.5 & 11.2 & 3.2 \\
\hline 10 & 101.7 & 9.8 & 7.9 & 6963 & 167.4 & 83.3 & 14.8 & 4.2 \\
\hline
\end{tabular}

weeks of the crop production cycle or on the average fresh or dry weight of the plants at crop termination time in either one of the experiments (data not shown).

As compared to the water control, a significant marketable yield increase was observed with a $2.5 \mathrm{ppm}$ (but not with a 5 or $10 \mathrm{ppm}$ ) kinetin spray in the Spring-Summer cucumber crop (Table 4); this positive effect on the marketable yield was not repeated in the Fall-Winter crop (Table 5). However, significant increases in the size of the marketable fruit with the 2.5 and 10 ppm kinetin spray concentrations,
Table 4. Effects of kinetin sprays on the marketable yield of 'Bodega' cucumber during the Spring-Summer 2004 season (harvest period: 22 June-15 July 2004).

\begin{tabular}{|c|c|c|c|}
\hline \multirow{2}{*}{$\begin{array}{l}\text { Kinetin spray concn } \\
{\left[(\mathrm{ppm}) \mathrm{mg} \cdot \mathrm{L}^{-1}\right]^{\mathrm{y}}}\end{array}$} & \multicolumn{2}{|c|}{ Marketable yield ${ }^{\mathrm{z}}$} & \multirow{2}{*}{$\begin{array}{c}\text { Avg wt of } \\
\text { marketable fruit } \\
\text { (g/fruit) }\end{array}$} \\
\hline & Fruit $^{x}$ (no./plant) & Fruit $^{\mathrm{x}}(\mathrm{g} / \text { plant })^{\mathrm{w}}$ & \\
\hline $0(\text { water })^{\mathrm{v}}$ & 6.4 & 2587 & 404 \\
\hline 2.5 & 8.1 & 3258 & 403 \\
\hline 5 & 7.4 & 3023 & 407 \\
\hline 10 & 7.0 & 2722 & 389 \\
\hline$P>\mathrm{F}$ & 0.049 & 0.047 & 0.124 \\
\hline
\end{tabular}

Fisher's protected $\operatorname{LSD}_{(0.05)}{ }^{\mathrm{u}} \quad 1.1 \quad 470$

${ }^{2}$ Marketable vield composed of extra-large, large, medium, small, and no. 2 fruit grades.

${ }^{\mathrm{K}}$ Kinetin sprayed at three stages: transplant stage, $5 \%$ to $10 \%$ blooming stage, and early fruiting stage.

${ }^{\mathrm{x}}$ Means of three replicates.

w $1 \mathrm{~g}=0.0353 \mathrm{oz}$.

vPlants sprayed with distilled water.

uLeast significant difference $(P \leq 0.05)$.

Table 5. Effects of kinetin sprays on the yield of 'Bodega' cucumber during the Fall-Winter 2004 season (harvest period: 1-28 Oct. 2004).

\begin{tabular}{|c|c|c|c|c|c|c|c|c|c|c|c|c|c|}
\hline \multirow[b]{3}{*}{$\begin{array}{l}\text { Kinetin spray concn } \\
{\left[(\mathrm{ppm}) \mathrm{mg} \cdot \mathrm{L}^{-1}\right]^{\mathrm{x}}}\end{array}$} & \multicolumn{12}{|c|}{ Yield $^{\mathrm{z}}$} & \multirow{3}{*}{$\begin{array}{c}\text { Avg wt of } \\
\text { marketable } \\
\text { fruit } \\
(\mathrm{g} / \\
\text { fruit }^{\mathrm{w}}\end{array}$} \\
\hline & \multicolumn{2}{|c|}{$\begin{array}{l}\text { Large } \\
\text { fruit }\end{array}$} & \multicolumn{2}{|c|}{$\begin{array}{l}\text { Medium } \\
\text { fruit }\end{array}$} & \multicolumn{2}{|c|}{$\begin{array}{l}\text { Small } \\
\text { fruit }\end{array}$} & \multicolumn{2}{|c|}{$\begin{array}{l}\text { No. } 2 \\
\text { fruit }\end{array}$} & \multicolumn{2}{|c|}{$\begin{array}{c}\text { Marketable } \\
\text { fruit }^{y}\end{array}$} & \multicolumn{2}{|c|}{$\begin{array}{c}\text { Unmarketable } \\
\text { fruit }\end{array}$} & \\
\hline & $\begin{array}{l}\text { (no./ } \\
\text { plant) }\end{array}$ & $\begin{array}{c}(\mathrm{g} / \\
\text { plant })^{\mathrm{w}}\end{array}$ & $\begin{array}{l}\text { (no./ } \\
\text { plant) }\end{array}$ & $\begin{array}{c}(\mathrm{g} / \\
\text { plant })\end{array}$ & $\begin{array}{l}\text { (no./ } \\
\text { plant) }\end{array}$ & $\begin{array}{c}(\mathrm{g} / \\
\text { plant })\end{array}$ & $\begin{array}{l}\text { (no./ } \\
\text { plant) }\end{array}$ & $\begin{array}{c}(\mathrm{g} / \\
\text { plant })\end{array}$ & $\begin{array}{l}\text { (no./ } \\
\text { plant })\end{array}$ & $\begin{array}{c}(\mathrm{g} / \\
\text { plant })\end{array}$ & $\begin{array}{l}\text { (no./ } \\
\text { plant) }\end{array}$ & $\begin{array}{l}\text { (g/fruit } \\
\text { plant) }\end{array}$ & \\
\hline $0\left(_{\text {water })^{\mathrm{v}}}\right.$ & 0.06 & 30 & 2.94 & 1173 & 7.38 & 2435 & 1.56 & 405 & 11.94 & 4042 & 0.13 & 33 & 334 \\
\hline 2.5 & 0.31 & 186 & 3.44 & 1448 & 6.38 & 2207 & 1.31 & 406 & 11.44 & 4247 & 0.25 & 58 & 371 \\
\hline$P>\mathrm{F}$ & 0.264 & 0.272 & 0.031 & 0.019 & 0.302 & 0.763 & 0.617 & 0.811 & 0.302 & 0.049 & 0.253 & 0.303 & 0.009 \\
\hline Fisher's protected & & & & & & & & & & & & & \\
\hline $\operatorname{LSD}_{(0.05)}{ }^{\mathrm{u}}$ & --- & --- & 0.76 & 323 & --- & --- & --- & --- & --- & 288 & --- & --- & 19 \\
\hline
\end{tabular}

${ }^{\mathrm{z}}$ Means of four replicates.

Marketable yield composed of large, medium, small, and no. 2 fruit grades.

${ }^{x}$ Kinetin sprayed at three stages: transplant stage, $5-10 \%$ blooming stage, and early fruiting stage.

"l $\mathrm{g}=0.0353 \mathrm{oz}$.

"Plants prayed with distilled water.

uLeast significant difference $(P \leq 0.05)$. 
and in the number and weight of the medium size fruit with the $10 \mathrm{ppm}$ kinetin spray indicated significant positive effects of the kinetin sprays on the cucumber grades in the Fall-Winter crop (Table 5).

During the Spring-Summer season, there were significant quadratic effects of kinetin spray concentration on both number and weight of marketable fruit. The dependence of marketable yield of cucumber on kinetin spray concentration was best described by the equations: 1) marketable fruit (number/plant) $=6.63$ $+0.457 \mathrm{X}-0.043 \mathrm{X}^{2}\left(\mathrm{R}^{2}=0.54^{*} ; \mathrm{Q}^{*}\right)$ and 2 ) marketable fruit (grams/plant) $=2665.45+202.87 \mathrm{X}-19.98 \mathrm{X}^{2}\left(\mathrm{R}^{2}\right.$ $\left.=0.57^{*} ; Q^{* *}\right)$, where $X$ is the kinetin spray concentration (parts per million), $\mathrm{Q}$ is the quadratic coefficient, and, * and ** indicate $5 \%$ and $1 \%$ level of significance, respectively. The Q in both cases was negative and significantly different from zero, indicating a decreasing marginal yield response to increasing kinetin spray concentration. The $\mathrm{R}^{2}$ measured the strength of the relationship between marketable yield (fruit number or fruit weight) and kinetin spray concentration. Even though both equations had significant $\mathrm{R}^{2}$ values, they could explain no more than $54 \%$ (fruit number) or $57 \%$ (fruit weight) of the actual variation in the corresponding data set. The regression equations gave the maximum response at 5.3 and $5.1 \mathrm{ppm}$ kinetin concentrations for marketable fruit number and weight, respectively.

Tомато. Kinetin sprays at 2.5 $\mathrm{ppm}$ resulted in a significant increase in fresh weight of leaves of tomato transplants in the Spring-Summer crop (Table 6). There were also significant gains in the fresh weight of stems $(2.5$ and $10 \mathrm{ppm}$ ) and dry weight of both leaves $(2.5 \mathrm{ppm})$ and stems (10 ppm) in the Spring-Summer crop (Table 6). However, kinetin sprays had no significant effect on any of the seedling growth parameters in the Fall-Winter crop (Table 6), except for a significant loss in the fresh weight of leaves ( 5 and $10 \mathrm{ppm}$ ).

Kinetin sprays had no significant effect on plant growth, flower development and fruit set of tomato during the first six weeks of the crop production cycle or on the average fresh and dry weight of plants at crop termination (data not shown).

A $2.5 \mathrm{ppm}$ kinetin spray resulted in significantly higher number and weight of extra-large grade tomato in the Fall-Winter crop (Table 7).
Pepper. The kinetin sprays on pepper seedlings significantly increased the leaf area ( 5 and $10 \mathrm{ppm})$, the fresh and dry weight of leaves $(2.5$ and 5 $\mathrm{ppm})$, the fresh weight of stems (5 $\mathrm{ppm})$, and the dry weight of stems (2.5 and $5 \mathrm{ppm}$ ) in the Spring-Summer crop (Table 8); the effects on the leaf area and fresh and dry weight of stems were also significant in the Fall-Winter crop (5 and $10 \mathrm{ppm}$ ). Furthermore, the kinetin sprays at 5 and 10 ppm significantly increased plant height and stem diameter of pepper transplants in the Fall-Winter crop. Kinetin spray concentration had significant positive correlations at the $5 \%\left({ }^{*}\right)$ or $1 \%(* *)$ level with plant height $\left(\mathrm{r}=0.28^{*}\right)$ and stem diameter $\left(\mathrm{r}=0.26^{*}\right)$ in the Spring-Summer crop, and with plant height $\left(\mathrm{r}=0.83^{* *}\right)$, stem diameter $(\mathrm{r}$ $\left.=0.54^{* *}\right)$, leaf area $\left(\mathrm{r}=0.62^{* *}\right)$, and fresh $\left(r=0.69^{* *}\right)$ and dry $\left(r=0.58^{* *}\right)$ weight of stem in the Fall-Winter crop. Regarding the appropriate concentration of the kinetin spray, $5 \mathrm{ppm}$ has been the best for pepper transplant growth.

The effects of the kinetin sprays on plant growth, flower development, and fruit set during the first 6 weeks of the crop production cycle or fresh and dry weight of plants at crop termination

Table 6. Effects of kinetin sprays on the growth of 'Rapsodie' tomato seedlings during the Spring-Summer and Fall-Winter 2004 seasons.

\begin{tabular}{|c|c|c|c|c|c|c|c|c|}
\hline \multirow{2}{*}{$\begin{array}{l}\text { Kinetin spray concn } \\
{\left[(\mathrm{ppm}) \mathrm{mg} \cdot \mathrm{L}^{-1}\right]}\end{array}$} & \multirow{2}{*}{$\begin{array}{c}\text { Plant } \\
\text { ht }^{\mathrm{y}}(\mathrm{cm})^{\mathrm{x}}\end{array}$} & \multirow{2}{*}{$\begin{array}{c}\text { Leaves }^{\mathrm{y}} \\
\text { (no./plant) }\end{array}$} & \multirow{2}{*}{$\begin{array}{l}\text { Stem diam } \\
(\mathbf{m m})^{\mathrm{x}}\end{array}$} & \multirow{2}{*}{$\begin{array}{l}\text { Leaf area } \\
\left(\mathrm{cm}^{2} / \text { plant }^{\mathrm{x}}\right.\end{array}$} & \multicolumn{2}{|c|}{$\begin{array}{l}\text { Fresh wt }{ }^{\mathrm{z}} \\
(\mathrm{g} / \text { plant })^{\mathrm{x}}\end{array}$} & \multicolumn{2}{|c|}{$\begin{array}{l}\text { Dry wt }{ }^{\mathrm{z}} \\
\text { (g/plant) }\end{array}$} \\
\hline & & & & & Leaves & Stem & Leaves & Stem \\
\hline \multicolumn{9}{|c|}{ Spring-Summer 2004" } \\
\hline $0(\text { water })^{\mathrm{v}}$ & 36.0 & 9.6 & 11.3 & 1489 & 57.2 & 25.8 & 6.2 & 1.9 \\
\hline 2.5 & 37.0 & 9.4 & 11.9 & 1843 & 66.9 & 29.8 & 7.4 & 2.1 \\
\hline 5 & 36.3 & 9.6 & 11.1 & 1619 & 58.8 & 26.8 & 6.3 & 2.1 \\
\hline \multicolumn{9}{|l|}{ Fisher's protected } \\
\hline $\operatorname{LSD}_{(0.05)}{ }^{\mathrm{u}}$ & --- & --- & --- & --- & 5.8 & 2.6 & 0.7 & 0.2 \\
\hline \multicolumn{9}{|c|}{ Fall-Winter $2004^{\mathrm{t}}$} \\
\hline 0 (water) & 52.2 & 12.0 & $\mathrm{ND}^{\mathrm{s}}$ & 2787 & 118.5 & 56.0 & 12.2 & 4.4 \\
\hline 2.5 & 53.4 & 11.8 & ND & 3056 & 115.2 & 59.5 & 12.4 & 4.3 \\
\hline \multicolumn{9}{|l|}{ Fisher's protected } \\
\hline $\mathrm{LSD}_{(0.05)}$ & --- & --- & --- & 374 & 15.5 & --- & --- & --- \\
\hline $\begin{array}{l}{ }^{2} \text { Means of five observations. } \\
{ }^{2} \text { Means of } 20 \text { observations. } \\
{ }^{2} 1 \mathrm{~cm}=0.3937 \text { inch, } 1 \mathrm{~mm} \\
\text { "Kinetin sprayed on } 18 \text {-d-ol } \\
\text { "Plants sprayed with distilled } \\
\text { "Least significant difference } \\
\text { 'Kinetin sprayed on } 21-\mathrm{d}-\mathrm{old} \\
\text { 'Not determined. }\end{array}$ & $\begin{array}{l}394 \text { inch, } 1 \mathrm{cr} \\
\text { dlings and gro } \\
\text { er. } \\
0.05 \text { ). } \\
\text { dlings and gror }\end{array}$ & $\begin{array}{l}=0.1550 \text { inch }^{2}, 1 \\
\text { parameters meas }\end{array}$ & $\begin{array}{l}0.0353 \mathrm{oz} \text {. } \\
\text { at } 15 \mathrm{~d} \text { thereaf } \\
\text { at } 21 \mathrm{~d} \text { thereaf }\end{array}$ & & & & & \\
\hline
\end{tabular}


Table 7. Effects of kinetin sprays on the yield of 'Rapsodie' tomato during the Spring-Summer and Fall-Winter 2004 seasons.

\begin{tabular}{|c|c|c|c|c|c|c|}
\hline \multirow{2}{*}{$\begin{array}{l}\text { Kinetin spray concn } \\
{\left[(\mathrm{ppm}) \mathrm{mg} \cdot \mathrm{L}^{-1}\right]^{\mathrm{y}}}\end{array}$} & \multicolumn{2}{|c|}{$\begin{array}{l}\text { Marketable fruit yield } \\
\text { of Spring-Summer crop }\end{array}$} & \multicolumn{2}{|c|}{$\begin{array}{l}\text { Yield of extra-large fruit } \\
\text { of Fall-Winter crop }\end{array}$} & \multicolumn{2}{|c|}{$\begin{array}{l}\text { Marketable fruit yield } \\
\text { of Fall-Winter crop }\end{array}$} \\
\hline & ${\text { (no./plant })^{x}}$ & $(g / \text { plant })^{x, w}$ & (no./ plant) $^{v}$ & $(\mathrm{~g} / \text { plant })^{\mathrm{v}}$ & (no./plant) $^{\mathrm{v}}$ & $(\mathrm{g} / \text { plant })^{\mathrm{v}}$ \\
\hline 2.5 & 14.6 & 2335 & 6.1 & 1385 & 20.5 & 3173 \\
\hline 5 & 14.0 & 2159 & 4.9 & 1092 & 20.2 & 2986 \\
\hline 10 & 13.9 & 2241 & 4.9 & 1058 & 21.0 & 3062 \\
\hline $\operatorname{LSD}_{(0.05)}{ }^{\mathrm{t}}$ & --- & --- & 0.9 & 213 & --- & --- \\
\hline
\end{tabular}

${ }^{2}$ Marketable yield composed of extra-large, large, small, and no. 2 fruit grades.

y Kinetin sprayed at three stages: transplant stage, 5 - $10 \%$ blooming stage, and early fruiting stage.

${ }^{x}$ Means of three replicates (harvest period: 6 Aug. -4 Sept. 2004).

w $1 \mathrm{~g}=0.0353 \mathrm{oz}$.

${ }^{\vee}$ Means of four replicates (harvest period: 25 Nov. 2004-7 Feb. 2005).

"Plants sprayed with distilled water.

tLeast significant difference $(P \leq 0.05)$.

Table 8. Effects of kinetin sprays on the growth of '4-Ever' and '444' pepper seedlings during the Spring-Summer and Fall-Winter 2004 seasons, respectively.

\begin{tabular}{|c|c|c|c|c|c|c|c|c|}
\hline \multirow{2}{*}{$\begin{array}{l}\text { Kinetin spray concn } \\
{\left[(\mathrm{ppm}) \mathrm{mg} \cdot \mathrm{L}^{-1}\right]}\end{array}$} & \multirow{2}{*}{$\begin{array}{c}\text { Plant } \\
\text { ht }^{\mathrm{y}}(\mathrm{cm})^{\mathrm{x}}\end{array}$} & \multirow{2}{*}{$\begin{array}{c}\text { Leaves }^{\mathrm{y}} \\
\text { (no./plant) }\end{array}$} & \multirow{2}{*}{$\begin{array}{l}\text { Stem diam } \\
\qquad(\mathrm{mm})^{\mathrm{x}}\end{array}$} & \multirow{2}{*}{$\begin{array}{l}\text { Leaf area } \\
\left(\mathrm{cm}^{2} / \text { plant }\right)^{x}\end{array}$} & \multicolumn{2}{|c|}{$\begin{array}{l}\text { Fresh wt }{ }^{\mathrm{z}} \\
\text { (g/plant) }\end{array}$} & \multicolumn{2}{|c|}{$\begin{array}{c}\text { Dry wtz } \\
\text { (g/plant) }\end{array}$} \\
\hline & & & & & Leaves & Stem & Leaves & Stem \\
\hline \multicolumn{9}{|c|}{ Spring-Summer $2004^{\mathrm{w}}$} \\
\hline $0(\text { water })^{\mathrm{v}}$ & 29.1 & 21 & 8.9 & 814 & 24.1 & 16.6 & 3.1 & 2.0 \\
\hline 2.5 & 30.9 & 22 & 9.3 & 940 & 29.2 & 18.7 & 4.1 & 2.5 \\
\hline 5 & 30.5 & 21 & 10.1 & 1041 & 32.4 & 21.0 & 4.3 & 2.6 \\
\hline 10 & 30.5 & 22 & 9.5 & 960 & 27.9 & 18.0 & 3.4 & 2.0 \\
\hline$P>\mathrm{F}$ & 0.160 & 0.782 & 0.173 & 0.015 & 0.005 & 0.017 & 0.001 & 0.010 \\
\hline \multicolumn{9}{|l|}{ Fisher's protected } \\
\hline $\operatorname{LSD}_{(0.05)}{ }^{\mathrm{t}}$ & --- & --- & --- & 133 & 4.3 & 2.6 & 0.6 & 0.4 \\
\hline \multicolumn{9}{|c|}{ Fall-Winter 2004 } \\
\hline 0 (water) & 21.8 & 19. & 7.5 & 720 & 30.5 & 11.3 & 3.3 & 1.1 \\
\hline 2.5 & 22.8 & 22 & 8.5 & 885 & 31.7 & 13.8 & 2.9 & 1.3 \\
\hline 5 & 31.8 & 22 & 9.6 & 1016 & 38.8 & 22.4 & 3.8 & 2.2 \\
\hline 10 & 32.6 & 21 & 9.1 & 1071 & 36.6 & 21.6 & 3.6 & 1.9 \\
\hline$P>\mathrm{F}$ & $1.0 \times 10^{-4}$ & 0.465 & 0.007 & 0.019 & 0.360 & $4.0 \times 10^{-4}$ & 0.480 & 0.003 \\
\hline \multicolumn{9}{|l|}{ Fisher's protected } \\
\hline $\operatorname{LSD}_{(0.05)}{ }^{\mathrm{t}}$ & 2.7 & --- & 1.4 & 230 & -- & 5.2 & -- & 0.6 \\
\hline \multicolumn{9}{|c|}{ 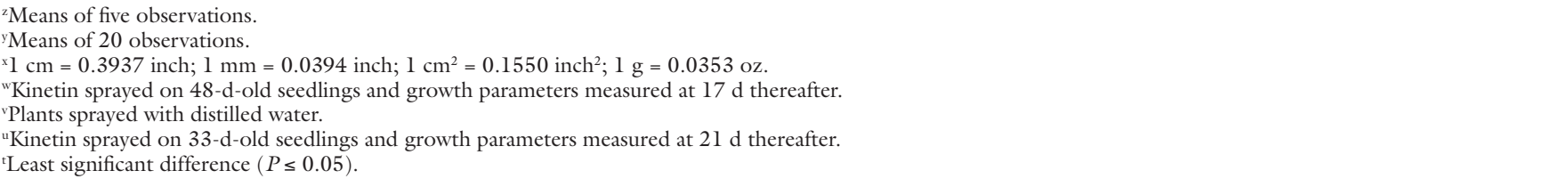 } \\
\hline
\end{tabular}

were nonsignificant (data not shown). However, there was a significant increase over the water control in the weight of the extra large fruit and the number of large fruit, as well as in the number and weight of all marketable fruit with a 10 ppm kinetin spray in the Spring-Summer pepper crop (Table9). Similar increases in the weight of large fruit were also observed with 2.5 and 5 ppm spray treatments. The Fall-Winter experiment did not provide reliable fruit yield data because of prevailing poor light condition in the wintertime.
Further statistical analysis of the Spring-Summer season data showed a significant linear effect of kinetin spray concentration on both number and weight of marketable fruit. The simple linear regression equations that best described the yield data were: 1 ) marketable fruit (number/plant) = $8.57+0.194 \mathrm{X}\left(\mathrm{r}^{2}=0.37^{*} ; \mathrm{L}^{*}\right)$ and 2) marketable fruit (grams/plant) $=$ $1684.88+28.64 \mathrm{X}\left(\mathrm{r}^{2}=0.36^{*} ; \mathrm{L}^{*}\right)$, where $\mathrm{X}$ is the kinetin spray concentration (parts per million), $\mathrm{L}$ is the linear coefficient, and * indicates $5 \%$ level of significance. Both equations had significant $r^{2}$ values. However, the numerical values of $r^{2}$ suggest that the equations presented above could explain only $37 \%$ (fruit number) or $36 \%$ (fruit weight) of the actual variation in the corresponding data set.

\section{Discussion and conclusions}

We have shown that a $2.5 \mathrm{ppm}$ kinetin spray can produce beneficial effects on the growth of young cucumber plants (Table 3). These effects (taller plants, larger leaf area, greater fresh 
Table 9. Effects of kinetin sprays on the yield of '4-Ever' pepper during the Spring-Summer 2004 season (harvest period: 10 Aug. to 6 Dec. 2004).

\begin{tabular}{|c|c|c|c|c|c|c|c|c|c|c|c|c|c|}
\hline \multirow[b]{3}{*}{$\begin{array}{l}\text { Kinetin spray concn } \\
{\left[(\mathrm{ppm}) \mathrm{mg} \cdot \mathrm{L}^{-1}\right]^{\mathrm{x}}}\end{array}$} & \multicolumn{12}{|c|}{ Yield $^{\mathrm{z}}$} & \multirow{3}{*}{$\begin{array}{c}\text { Avg wt of } \\
\text { marketable } \\
\text { fruit } \\
\text { (g/ } \\
\text { fruit) }\end{array}$} \\
\hline & \multicolumn{2}{|c|}{$\begin{array}{c}\text { Extra-large } \\
\text { fruit }\end{array}$} & \multicolumn{2}{|c|}{$\begin{array}{l}\text { Large } \\
\text { fruit }\end{array}$} & \multicolumn{2}{|c|}{$\begin{array}{c}\text { Medium } \\
\text { fruit }\end{array}$} & \multicolumn{2}{|c|}{$\begin{array}{l}\text { Small } \\
\text { fruit }\end{array}$} & \multicolumn{2}{|c|}{$\begin{array}{l}\text { No. } 2 \\
\text { fruit }\end{array}$} & \multicolumn{2}{|c|}{$\begin{array}{c}\text { Marketable } \\
\text { fruit }^{\mathrm{y}}\end{array}$} & \\
\hline & $\begin{array}{l}\text { (no./ } \\
\text { plant) }\end{array}$ & $\begin{array}{c}(\mathrm{g} / \\
\text { plant }^{\mathrm{w}}\end{array}$ & $\begin{array}{l}\text { (no./ } \\
\text { plant) }\end{array}$ & $\begin{array}{c}(\mathrm{g} / \\
\text { plant })\end{array}$ & $\begin{array}{l}\text { (no./ } \\
\text { plant) }\end{array}$ & $\begin{array}{c}(\mathrm{g} / \\
\text { plant })\end{array}$ & $\begin{array}{l}\text { (no./ } \\
\text { plant) }\end{array}$ & $\begin{array}{c}(\mathrm{g} / \\
\text { plant })\end{array}$ & $\begin{array}{l}\text { (no./ } \\
\text { plant) }\end{array}$ & $\begin{array}{c}(\mathrm{g} / \\
\text { plant })\end{array}$ & $\begin{array}{l}\text { (no./ } \\
\text { plant) }\end{array}$ & $\begin{array}{l}\text { (g/fruit } \\
\text { plant) }\end{array}$ & \\
\hline $0(\text { water })^{v}$ & 5.7 & 1247 & 1.6 & 251 & 1.0 & 137 & 0.3 & 22 & 0.3 & 40 & 8.7 & 1697 & 194 \\
\hline 2.5 & 5.3 & 1205 & 2.2 & 371 & 1.1 & 146 & 0.2 & 13 & 0.4 & 58 & 9.2 & 1794 & 196 \\
\hline $\begin{array}{l}P>\mathrm{F} \\
\text { Fisher's protected }\end{array}$ & 0.049 & 0.036 & 0.049 & 0.049 & 0.994 & 0.999 & 0.394 & 0.534 & 0.011 & 0.010 & 0.049 & 0.049 & 0.98 \\
\hline $\operatorname{LSD}_{(0.05)}{ }^{u}$ & 0.7 & 170 & 0.6 & 113 & -- & -- & -- & -- & -- & -- & 1.4 & 260 & --- \\
\hline
\end{tabular}

${ }^{2}$ Means of three replicates.

"Marketable yield composed of extra-large, large, medium, small, and no. 2 fruit grades.

${ }^{x}$ Kinetin sprayed at three stages: transplant stage, $5 \%$ to $10 \%$ blooming stage, and early fruiting stage.

${ }^{\mathrm{w}} 1 \mathrm{~g}=0.0353 \mathrm{oz}$.

Plants sprayed with distilled water.

"Least significant difference $(P \leq 0.05)$.

and dry weight), theoretically, should result in more light interception at an early stage in the life of the plants, resulting in higher productivity of the canopy. The final anticipated outcome of these effects ought to be higher plant productivity. The higher marketable yield of cucumber with $2.5 \mathrm{ppm}$ kinetin sprays (compared to the water control) in the Spring-Summer crop (Table 4 ) and the significant improvements in fruit size $(2.5$ and $10 \mathrm{ppm})$ and grades (10 ppm) in Fall-Winter crop (Table 5) are further evidence that overall the kinetin sprays are beneficial to cucumber. However, higher concentrations of kinetin (10 ppm) during the Spring-Summer season, gave a reduced yield as compared to 2.5 ppm kinetin (Table 4). The significant negative quadratic coefficients we found for both fruit number and weight suggest a negative dose response of cucumber yield to kinetin above a certain threshold concentration. According to the regression equations, these threshold concentrations were 5.3 and 5.1 ppm for marketable fruit number and weight, respectively. In the multi-location field studies conducted by Staub et al. (1987), treatment of cucumber seeds with commercial cytokinin (Cytozyme and Cytex) did not result in any significant increase in marketable yield. In our study, positive yield response of cucumber to foliar application of kinetin was not stable throughout the growing seasons, warranting further work to test the repeatability of the yield results.

A 2.5 ppm kinetin spray during the Spring-Summer season had beneficial effects also on the growth of tomato seedlings (Table 6). This treatment gave superior transplant quality as revealed by higher fresh and dry leaf weight as well as fresh weight of stem (Table 6). However, most of these positive effects on seedlings were not repeated in the Fall-Winter crop, and did not result in a higher marketable yield, expressed as either number or weight of fruit (Table 7). Csizinszky et al. (1990) also reported that soil and foliar application of a commercial biostimulant, Triggr, containing cytokinin as kinetin, neither increased the early nor the total marketable yield of tomato throughout the season. Cytokinin foliar sprays (14 and $28 \mathrm{~d}$ after transplanting) from Cytex on 'Sunny' tomato resulted in an increased $(70 \%$ over control) yield of large fruit, while 'Hayslip' appeared less responsive (Csizinszky, 1986). Summarizing the 5 years of PGR research results on both Spring and Fall tomato, Csizinszky (1996) reported that the positive PGR effects on fruit size and yield of tomato were also inconsistent from year to year, as observed in the present study.

In contrast to cucumber and tomato plants, the positive effects of kinetin sprays on the growth of pepper transplants (Table 8 ) were more prevalent and consistent throughout the year (Spring-Summer and Fall-Winter seasons). Pepper yield was evaluated only in a short Spring-Summer crop, where it showed significant gains with high concentration (10 ppm) kinetin spray. The significant positive linear yield response to kinetin spray concentration suggests further that pepper would require a high spray concentration $(10 \mathrm{ppm})$. Our results are in partial agreement with those reported by Csizinszky et al. (1990) where soil and foliar application of a commercial biostimulant, Triggr, containing cytokinin as kinetin, increased marketable yield of bell pepper throughout the season. Positive yield response of pepper to root application of kinetin has also been reported by Nickell (1986).

In general, the results of this study are in good agreement with those of an extensive survey conducted by Vavrina (2001) on the performance of various PGRs on different vegetables, where it has been reported that the benefits of PGR use by vegetable growers were inconsistent from year to year as well as from one cultivar to the other.

In conclusion, kinetin sprays at appropriate concentrations are beneficial in increasing the yield of cucumber and pepper during the Spring-Summer season, and the fruit size of cucumber and tomato in the Fall-Winter. However, further studies are needed to establish the consistency of effects across cultivars and seasons, and to determine the appropriate concentration under low and high photosynthetic photon flux density conditions. It must be noted that given the rather short-term nature of our experiments, the observed beneficial effects of the kinetin sprays on yield can only be interpreted as beneficial effects on early yield rather than on the total yield of a full-season greenhouse vegetable crop. 


\section{Literature cited}

Barciszewski J., S.I.S. Rattan, G. Sibiska, and B.F.C. Clark. 1998. Kinetin-45 years on. Plant Sci. 148:37-45.

Barciszewski, J., G. Siboska, S.I.S. Rattan, and B.F.C. Clark. 2000. Occurrence, biosynthesis and properties of kinetin ( N6furfuryladenine). Plant Growth Regulat. 32:257-265.

Bugbee, B. and J.W. White. 1984. Tomato growth as affected by root-zone temperature and the addition of gibberellic acid and kinetin to nutrient solution. J. Amer. Soc. Hort. Sci. 109:121-125.

Clifford, P.E., C.E. Offler, and J.W. Patrick. 1986. Growth regulators have rapid effects on photosynthate unloading from seed coats of Phaseolus vulgaris L. Plant Physiol. 80:635-637.

Csizinszky, A.A. 1986. Response of tomatoes to foliar biostimulant sprays. Proc. Fla. State Hort. Soc. 99:353-358.

Csizinszky, A.A. 1994. Yield response of tomato, cv. Agriset 761, to seaweed spray, micronutrient, and $\mathrm{N}$ and $\mathrm{K}$ rates. Proc. Fla. State Hort. Soc. 107:139-142.

Csizinszky, A.A. 1996. Foliar and soil applied biostimulants for fresh-market tomatoes in Florida. Proc. Interamerican Soc. Trop. Hort. 40:246-252.

Csizinszky, A.A., C.D. Stanley, and G.A. Clark. 1990. Foliar and soil-applied biostimulant studies with microirrigated pepper and tomato. Proc. Fla. State Hort. Soc. 103:113-117.

Dong, C-N. and R.N. Arteca. 1982. Changes in photosynthetic rates and growth following root treatments of tomato plants with phytohormones. Photosyn. Res. 3:45-52.
Flaishman, M.A., A. Shargal, R.A. Stern, S. Lev-Yadum, and G. Grafi. 2005. The synthetic cytokinins CPPU and TDZ prolong the phase of cell division in developing pear (Pyrus communis L.) fruit. Acta Hort. 671:151-157.

Gaudinova, A. 1990. The effect of cytokinins on nitrate reductase activity. Biologia Plant. 32:89-96.

Karagiannis, C.S. and A.J. Pappelis.1994. Effect of abscisic acid, gibberellic acid, indoleacetic acid and kinetin on selective ribosomal cistron regulation in questien and senescent onion leaf base tissue. Mechanisms Aging Dev. 20:145-155.

Kelling, K.A. 2004. Non conventional soil additives: products, companies, ingredients, and claims. 15 July 2005. <http://www. soils.wisc.edu/extension/hottopics/nonconventional.pdf>.

Nickell, L.G. 1986. Effects of N-(2chloro-4-pyridyl)-N and phenyl urea on grapes and other crops. Proc. 13th Annu. Mtg. Plant Growth Regulat. Soc. Amer. p. 236-241.

Ontario Ministry of Agriculture and Food. 1987. Greenhouse tomato grading and packing manual, regulation 378/90, the Farm Products Grades and Sales Act. Govt. of Ontario, Guelph, Canada.

Ozga, J.A. and D.M. Reinecke. 2003. Hormonal interaction in fruit development. J. Plant Growth Regulat. 22:73-81.

Papadopoulos, A.P. 1991. Growing greenhouse tomatoes in soil and soilless media. Agriculture and Agri-Food Canada Publ. $1865 / \mathrm{E}$.

Papadopoulos, A.P. 1998. Seasonal fertigation schedules for greenhouse tomatoes-Concepts and delivery systems. Acta Hort. 458:123-140.
Papadopoulos, A.P. and N. Liburdi. 1989. The Harrow fertigation manager ${ }^{\circledR}$, a computerized multifertilizer injector. Acta Hort. 260:255-266.

Russo, R.O. and G.P. Berlyn. 1990. The use of organic biostimulants to help low input agriculture. J. Sustainable Agr. 1:19-42.

Russo, R.O. and G.P. Berlyn. 1992. Vitamin-humic-algal root biostimulant increases yield of green bean. HortScience 27:847.

Staub, J.E., T.C. Wehner, and G.E. Tolla. 1987. Effect of treatment of cucumber seeds with growth regulators on emergence and yield of plants in the field. Acta Hort. 198:43-52

Ulvskov, P., T.H. Nielsen, P. Seiden, and J. Marcussen. 1992. Cytokinins and leaf development in sweet pepper (Capsicum annuum L.). I. Spatial distribution of endogenous cytokinins in relation to leaf growth. Planta 188:70-77.

Verkleij, F.N. 1992. Seaweed extracts in agriculture and horticulture: A review. Biol. Agr. Hort. 8:309-324.

Vavrina, C.S. 2001. Chemical stimulation of plant growth of vegetables in Florida, EDIS HS816, 15 July 2005. <http:/ / edis. ifas.ufl.edu/HS110>.

Wilczek, C.A. and J.T. Ng. 1982. Promotion of seed germination in table beet by an aqueous seaweed extract. HortScience 17:629-630.

Younis, M.E., O.A. El-Shahaby, M.M.N. Alla, and Z.M. El-Bastawisy. 2003. Kinetin alleviates the influence of waterlogging and salinity on growth and affects the production of plant growth regulators in Vigna sinensis and Zea mays. Agronomie 23:277-285. 